20. Monitoring and Assessing Progress on Decent Work / International Labour Organization. URL: https://www.ilo.org/integration/themes/mdw/ map/lang--en/index.htm (in English).

21. ILO Centenary Declaration for the Future of Work. URL: https://www.ilo.org/wcmsp5/groups/public/---ed_norm/---relconf/documents/ meetingdocument/wcms 711674.pdf (in English).

22. Saharuk I.S. Kljuchovi vektory rozvytku trudovogo zakonodavstva v konteksti Deklaracii' stolittja MOP shhodo majbutn'ogo praci [The basic vectors of labor law development according to the ILO Centenary Declaration for the Future of Work]. Visnyk Pivdennogo regional'nogo centru Nacional'noi' akademii' pravovyh nauk Ukrai'ny. 2019. №20. S.87-95 (in Ukrainian).

23. The need for social dialogue in addressing the COVID-19 crisis. Briefing note / International Labour Organization. 05 May 2020. URL: https://www.ilo.org/global/about-the-ilo/how-the-ilo-works/departments-andoffices/governance/WCMS 743640/lang--en/index.htm (in English)

24. Rekomendacija MŌT №205 o zanjatosti i dostojnom trude v celjah obespechenija mira i potenciala protivodejstvija 2017. URL: https://www.ilo.org/

I. Sakharuk, PhD (Law), Associate Prof.

Taras Shevchenko National University of Kyiv, Kyiv, Ukraine
dyn/normlex/en/f?p=NORMLEXPUB:12100:0::NO::P12100_ILO_CODE:R205 (in Russian).

25. Building a better future of work: ILO Global Summit on COVID-19 and the World of Work Concept note. / International Labour Organization. 15 June 2020. URL: https://www.ilo.org/global/topics/coronavirus/events/ WCMS_747476/lang--en/index.htm (in English).

Наукове дослідження проведено в рамках держбюджетної теми № 19БФ042-01M "Соціально-правові засади збереження та розвитку трудового потенціалу України"

Received: $11 / 05 / 2020$ 1st Revision: $05 / 06 / 2020$ Accepted: $17 / 06 / 2020$

\title{
A SOCIAL DIALOGUE AS THE BASIS FOR THE CONCEPT OF DECENT WORK IMPLEMENTATION
}

The article examines the concept of decent work as a strategic direction for the development of labour legislation of the XXI century. The article is devoted to the research on the social dialogue as a part of the concept of decent work and an instrument for the effective realization of its other parts. The author outlines the connections between the institute of social dialogue and such dimensions of the concept of decent work as fundamental principles and rights at work, employment and working conditions, social protection. The legal grounds for social dialogue in the strategic documents of the International Labour Organization, its features for the future of the labour and the special role in the conditions of COVID-19 pandemic are analysed.

The importance of the principle of freedom of association and the effective recognition of the right to collective bargaining for the effectiveness of social dialogue is established. The specifics of the influence of social dialogue to the realisation of the concept of decent work at the national and industrial levels are determined.

The paper substantiates the interdependence of economic development and social progress and a high-quality social dialogue. The author also identifies the role of social dialogue in the process of labour law development. A social dialogue is important for improving labour and social legislation, bringing it in line with the requirements of the labour market, the employers' and workers' needs. The issues of decent working conditions, harmonization of professional and family life and professional development of employees can be effectively addressed at the production level.

The author investigates the peculiarities of application and specific role of social dialogue for management of difficult situations and crises. It is stated that using the social dialogue to find solutions to the full range of problems by COVID-19 is important. It is determined, that it helps to analyse the real situation in various industries and spheres, reduce social tensions, minimize negative socio-economic consequences for all participants of social dialogue.

Keywords: the concept of decent work, a social dialogue, the Fundamental Principles and Rights at Work, freedom of association, employers' organizations, workers' organizations, collective bargaining, social justice, social development, COVID-19.

Bulletin of Taras Shevchenko National University of Kyiv.

Legal Studies, 2020; 2 (113): 61-66

УДК: 347.998: 349.2

DOI: https:doi.org/10.17721/1728-2195/2020/2.113-12
ISSN 1728-2195

(C) Taras Shevchenko National University of Kyiv,

Publishing center "Kyiv University", 2020

O. Терех, канд. юрид. наук, асист. ORCID ID: 0000-0002-6432-3787

Київський національний університет імені Тараса Шевченка, Київ, Україна

\section{АЛЬТЕРНАТИВНІ СПОСОБИ РОЗВ'ЯЗАННЯ ТРУДОВИХ СПОРІВ: ПРАКТИКА УКРАÏНИ ТА ЄС}

Досліджено альтернативні способи розв'язання трудових спорів крізь призму аналізу профільних нормативноправових актів України та держав-членів Європейського Союзу, зокрема Франції, Болгарії та Польщі, а також здійснено порівняння відповідного нормативно-правового регулювання шляхом зіставлення положень вітчизняного $і$ зарубіжного законодавства. Визначено переваги та недоліки таких способів, як медіація, примирення, арбітражний розгляд. Запропоновано шляхи вдосконалення чинного законодавства.

Зазначено, що відсутність належного правового регулювання альтернативних способів урегулювання спорів нині $\epsilon$ не єдиною проблемою на шляху становлення останніх. Наголошено на необхідності підготовки кадрів, які 6 могли виконувати функції медіаторів у трудових спорах, а також на потребі проводити маситабну інформаційну політику 3 метою інформування населення про переваги застосування альтернативних способів урегулювання спорів на противагу судовому, до яких автор, зокрема, відносить швидкість, ефективність і спрямованість на збереження трудових відносин. Розглянуто думку щодо доцільності запровадження обов'язкових досудових процедур урегулювання трудових спорів.

Ключові слова: трудовий конфлікт, медіація, примирення, третейські суди, арбітраж, комісія із трудових спорів.

ВСтУП. Сфрера трудових відносин $є$ однією із найбільш уразливих, ураховуючи неефективність та застарілість відповідного трудового законодавства на теренах України. Брак правового регулювання, довга тривалість судових процесів не узгоджуються із концептом людино-центризму та пріоритетом захисту прав людини. Таким чином, ураховуючи необхідність реалізації на практиці конституційних положень та зобов'язань, узятих на себе Україною перед європейським співтовари- ством, постає необхідність дослідження альтернативних, тобто позасудових, способів розв'язання трудових спорів, зокрема шляхом аналізу аналогічних правових інституцій, які існують і успішно фрункціонують у державах-членах Європейського Союзу.

Аналіз останніх наукових досліджень. Зазначимо, що лише окремі аспекти щодо функціонування альтернативних способів розв'язання трудових спорів були висвітлені в наукових працях, зокрема такими вченими, 
як Бурак В. Я., Давиденко Д. Л., Венедиктов В. С., Лазор В. В., Процевський О. І., Пилипенко П. Д. та ін.

Mema cmammi - дослідити способи альтернативного розв'язання трудових спорів шляхом аналізу відповідної правової доктрини та положень вітчизняного законодавства, а також законодавства держав-членів ЄС.

ВИКЛАД ОСНОВНОГО МАТЕРІАЛУ. Переходячи до висвітлення обраної проблематики по суті, передусім доцільно проаналізувати таку категорію як "трудовий спір". Слід зазначити, що в межах чинного українського законодавства відсутнє легальне визначення даного поняття. Наприклад, Кодекс законів про працю України хоч і використовує зазначене поняття в межах окремих статей, але не розкриває дану правову категорію. Закон України "Про порядок розв'язання колективних трудових спорів (конфлліктів)" визначає поняття "колективний трудовий спір" і встановлює, що це певні розбіжності, які виникли між сторонами соціальнотрудових відносин щодо: установлення нових або зміни існуючих соціально-економічних умов праці та виробничого побуту; укладення чи зміни колективного договору, угоди; виконання колективного договору, угоди або окремих їхніх положень; невиконання вимог законодавства про працю [1].

Юридична енциклопедія за редакцією Ю. С. Шемшученка визначає, що трудові спори - це неврегульовані розбіжності, які виникають між працівником і роботодавцем або між працівниками та роботодавцями 3 питань застосування законів, інших нормативноправових актів про працю та умов трудового договору чи встановлення або зміни умов праці, укладення угоди [2, с. 576]. Автор даного визначення, по-перше, виділяє такі види трудових спорів, як індивідуальні та колективні, а по-друге, визначає трудовий спір як неврегульовані розбіжності. Не можемо погодитися із такою характеристикою як неврегульованість з огляду на те, що відносини між працівниками та роботодавцями на сьогодні доволі детально регламентуються як різноманітними нормативно-правовими актами, так і положеннями трудового договору. В окремих випадках може застосовуватися також аналогія права або закону. 3 огляду на це більш доцільним видається визначення В. Н. Толкунової, яка зазначає, що трудові спори - це надіслані на розгляд юрисдикційного органу суперечності суб'єктів трудового права з питань застосування трудового законодавства чи встановлення нових умов праці [3, с. 261].

Загалом аналіз правової доктрини дає змогу виділити три основні підходи до розуміння поняття "трудовий спір". Відповідно до першого підходу трудовий спір слід розглядати як конфлікт, що виникає між персоніфрікованими суб'єктами, а саме між працівником і роботодавцем щодо застосування останнім норм трудового законодавства. У даному випадку відсутня множинність суб'єктів на кожній із сторін конфлікту. Другий підхід об'єднує погляди, які зводяться до того, що трудовий спір можна визначити як конфлікт, що виникає між колективом працівників і відповідним роботодавцем щодо реалізації останнім положень трудового законодавства. У цьому випадку має місце множинність суб'єктів, зокрема на боці працівників. Третій підхід розглядає трудовий спір як певний конфлікт, що виникає між працівником (працівниками) щодо реалізації останнім своїх повноважень, які сконцентровані у трудовій площині, але прямо не врегульовані нормами чинного законодавства, проте випливають із його суті.

Ураховуючи зазначене, на наш погляд, доцільно виділити такі ознаки поняття "трудовий спір", що розкривають зміст даної категорії: 1) може мати індивідуальний характер (працівник-роботодавець) або ж колекти- вний (працівники-роботодавець); 2) доцільно визначати як конфлікт або суперечність, яка виникає між суб'єктами трудових відносин; при цьому важливо, що трудовий спір може виникнути як безпосередньо із трудових відносин, так і з відносин, що безпосередньо з ними пов'язані, наприклад із правовідносин організаційноуправлінського характеру; 3) сторони спору не в змозі самостійно розв'язати такий спір, а тому готові передати його на розгляд відповідного юрисдикційного органу; ця характеристика відрізняє поняття "трудовий спір" від поняття "протиріччя", коли сторони можуть поговорити і самостійно розв'язати всі питання; 4) важливо, що спір може виникнути як у зв'язку із неправомірними діями роботодавця, так і працівника, тобто важливо, щоб обидві сторони трудових правовідносин мали можливість реалізувати конституційне право на захист своїх прав, свобод і законних інтересів, завдяки чому досягається відновлення порушених прав, попередження та припинення дій, що порушують або можуть порушити права та законні інтереси особи.

Вавженчук С. Я. констатує, що на практиці захист трудових прав зазвичай зводиться до судового, який $є$ доволі далеким від досконалості й не завжди забезпечує вчасний і оперативний захист порушених трудових прав, оскільки суди, по-перше, надмірно завантажені, а по-друге, сама діюча система розгляду та розв'язання трудових спорів потребує вдосконалення [4, с. 444]. Саме тому питання щодо застосування альтернативних способів розв'язання трудових спорів на сьогодні $€$ актуальним. Підписавши угоду про асоціацію із ЄС, Україна взяла на себе зобов'язання провести певні реформаційні дії, що будуть спрямовані на трансформацію правового регулювання, зокрема трудової сфери та сфери розв'язання трудових конфліктів, до європейських стандартів. У контексті цього доцільно зазначити, що європейське співтовариство все частіше для врегулювання трудових спорів використовує позасудові механізми, тобто альтернативні способи розв'язання трудових спорів, які відзначаються своєю швидкістю та ефективністю. Альтернативне розв'язання спорів визначається як група процесів, за допомогою яких розв'язуються спори, конфлікти і справи без звернення до судових розглядів [16]. Як зазначає Ізарова І. О., альтернативні способи розв'язання спорів забезпечують реальну можливість урегулювання спору без судового розгляду і подолання пов'язаних із цим проблем високої вартості, надмірної тривалості, складності, необхідності представництва інтересів у суді. Отже, запропоновані ЄС альтернативні способи розв'язання спорів мають передусім гарантувати пропорційні витрати, легкий доступ і ефективність розв'язання спору [17, с. 255].

У межах правової доктрини альтернативні способи розв'язання трудових спорів визначають як сукупність не заборонених законом процедур, спрямованих на мирне врегулювання суперечностей між сторонами на основі узгодження їхніх позицій та інтересів, які здійснюються самими сторонами конфлікту або із залученням інших осіб, для вироблення взаємоприйнятного рішення, що задовольняє інтереси кожної з них і має на меті врегулювання конфлікту [5, с. 65]. Загалом погоджуючись із даним визначенням, зазначимо лише, що, на наш погляд, урегулювання спору за допомогою альтернативних процедур здійснюється обов'язково із залученням третіх осіб. Оскільки, якщо сторони можуть самостійно владнати всі питання, які в них виникають одне до одного, то ця ситуація не має розглядатися як трудовий спір.

Для більш чіткого розуміння змісту альтернативних способів розв'язання трудових спорів виділимо їх основні характеристики: 1) участь у процедурі альтернатив- 
ного врегулювання спору здійснюється лише на добровільних засадах, що обумовлено необхідністю згоди кожної зі сторін на використання такого способу розв'язання трудового спору; 2) використання стратегії пошуку компромісу та стратегії співпраці, що обумовлено необхідністю не лише врегулювати трудовий спір, але і на основі взаємних поступок забезпечити задоволення інтересів учасників спору; 3) сторони трудового спору самостійно обирають конкретний спосіб із цілої низки альтернативних способів (це важливо, оскільки сторони самі вибирають найбільш прийнятний і доцільний для їхньої ситуації спосіб); 4) розв'язання трудового спору відбувається на приватних засадах і 3 дотриманням принципу конфіденційності (саме конфріденційність у багатьох випадках спонукає сторони конфлікту застосовувати альтернативні способи на противагу судовому розгляду, де діють принципи гласності та відкритості); 5) швидкість, економічність, зручна та проста форма розгляду, що спрямована на врегулювання трудового спору.

Переходячи до висвітлення питання щодо видів альтернативних способів розв'язання трудових спорів, зазначимо, що більшою мірою доцільно виділяти такі основні способи, як примирення, медіація та арбітраж.

I. Медіація як альтернативний спосіб розв'язання трудового спору. Медіація як спосіб розв'язання трудового спору широко застосовується на теренах Європейського Союзу. Медіація спрямована на те, щоб урегулювати спір за допомогою фактичних переговорів із залученням медіатора, тобто незалежного посередника. Уперше інститут медіації виник у англоамериканській правовій сім'ї та згодом знайшов своє нормативно-правове закріплення на європейському континенті. На сьогодні інститут медіації $€$ уніфрікованим, незважаючи на деякі диференціації правового регулювання певних сфер в окремих європейських державах. Зазначимо, що основою для формування інституту медіації була Директива Європейського парламенту "Про деякі аспекти медіації в цивільних і господарських спорах" від 21.05.2008. Директива закріпила основні зобов'язання, що мали бути виконані європейськими державами для становлення та розвитку медіації. До цих зобов'язань, зокрема, відносили: необхідність розроблення системи підготовки медіаторів, тобто, по суті, основних суб'єктів, діяльність яких спрямована на врегулювання спору між учасниками конфлікту. Держави мали розробити ефективну систему виконання рішень, прийнятих за результатами медіації, щоб процес медіації був спрямований на досягнення відповідних результатів, які полягали у фактичному, а не ілюзорному розв'язанні спору; забезпечити збереження права особи на звернення до суду за захистом відповідних прав; виробити практику забезпечення конфіденційності інформації, отриманої в ході проведення медіації [6]. В. Терехов зазначає, що на теренах Європейського Союзу медіацію визначають як структурований процес, у якому дві або більше сторін на добровільній основі намагаються досягти домовленості щодо конфлікту, який між ними виник, за участі медіатора. Учений виділяє такі основні риси медіації: 1) участь трьох суб'єктів: два суб'єкти - це сторони відповідного спору, а третій - нейтральний учасник, який пропонує свою допомогу в розв'язанні спору; 2) медіатор не здійснює функцій судді, він не оцінює докази та не ухвалює рішення, а лише допомагає сторонам розв'язати спір самостійно; 3) гнучка та неформалізована процедура проведення медіації; 4) медіація здебільшого застосовується у приватноправових спорах; 5) добровільна участь у процесі медіації; 6) медіація здебільшого проводиться у формі особистих зустрічей учасників конфолікту та медіатора [15].
Європейські держави, розуміючи необхідність розвантаження судової системи, реалізації концепту людино-центризму, на практиці розробили й успішно впровадили у власні правові системи процедуру медіації як альтернативного способу розв'язання трудових спорів. Зокрема, Франція була першою європейською державою, яка на законодавчому рівні закріпила положення про можливість урегулювання трудового спору за допомогою медіації. Статті 2523-1 та 2523-10 Трудового кодексу Франції визначають положення щодо медіації у трудових спорах [7]. Проаналізувавши відповідні норми, можемо встановити, що процес призначення медіації залежить від попередніх дій учасників конфлікту. Залучити медіатора може адміністративний орган з моменту виникнення конфлікту, тобто один із учасників спору звертається до уповноваженого державою суб'єкта публічного адміністрування 3 метою проведення процедури медіації для розв'язання трудової суперечки. Адміністративний орган, у свою чергу, призначає медіатора зі списку медіаторів, який фрормується Національною комісією з колективних переговорів. Можливий також інший варіант залучення медіатора, зокрема в тому випадку, коли голова комісії з урегулювання трудових спорів не розв'язав конфлікт. Процедура медіації має тривати не більше одного місяця. Однак у виняткових випадках термін може бути продовжено за згодою сторін і медіатора. Протягом відповідного терміну медіатор надає сторонам обґрунтовані рекомендації для врегулювання конфрлікту. Водночас, якщо медіатор виявить, що спір пов'язаний із тлумаченням або порушенням законодавчих положень чи договірних умов, то він рекомендує сторонам звернутися до суду для розв'язання цього спору. Якщо після одержання рекомендацій від медіатора сторони не погоджуються на запропоновані умови, то вони повинні у восьмиденний термін повідомити про це медіатора. Медіатор, у свою чергу, протягом 48 годин складає звіт про недосягнення примирення між сторонами і подає його до Міністерства праці Франції з усією супровідною документацією. Якщо ж сторони погодилися з умовами, запропонованими медіатором, то сам медіатор виступає в ролі суб'єкта, який контролює виконання умов медіації. Якщо одна зі сторін відмовляється або ж ухиляється від виконання умов медіаційної угоди, то медіатор може повідомити про це органи прокуратури Франції.

У Болгарії процедура медіації закріплена на рівні окремого законодавчого акту. Закон "Про медіацію" у ст. 3 визначає, що процедура медіації може бути застосована, зокрема, у трудових спорах [8]. Відповідно до зазначеного нормативно-правового акту медіація застосовується за наявності згоди обох сторін конфлікту. До процесу може бути залучено більше ніж одного медіатора. При цьому важливою умовою $€$ дотримання вимоги неупередженості медіатора. Медіатор у процесі врегулювання суперечки визначає предмет спору, інформує учасників про наслідки проведення тих чи інших дій, спрямованих на врегулювання спору. Якщо сторони досягають домовленості, то вони підписують відповідну угоду, яка $€$ обов'язковою лише для сторін конфлікту. Законодавство Болгарії не визначає чіткого переліку способів здійснення контролю за виконанням умов медіаційної угоди. Процедура медіації припиняється в разі врегулювання спору, з ініціативи однієї або обох сторін спору, у зв'язку зі смертю учасника або припиненням юридичної особи учасника конфлікту, а також у разі спливу шести місяців від початку процедури медіації, якщо згоди між учасниками не було досягнуто.

Аналізуючи вітчизняне законодавство, можна зазначити, що на сьогодні відсутні правові норми, які б регу- 
лювали не лише медіацію в трудових спорах, але й загалом інститут медіації. При цьому в межах Закону України "Про порядок розв'язання колективних трудових спорів (конфрліктів)" закріплено положення про діяльність незалежного посередника і відповідної Національної служби посередництва і примирення. Зазначимо, що положення даного закону поширюються лише на колективні трудові спори, залишаючи, таким чином, індивідуальні поза нормативно-правовим регулюванням. Окрім того, у суспільстві неодноразово розглядалося питання щодо ефективності роботи Національної служби посередництва і примирення, адже кількість урегульованих нею спорів $є$ мізерною порівняно 3 кількістю трудових спорів, що врегульовуються аналогічними європейськими інституціями.

Що ж стосується запровадження в Україні медіації, то це питання в межах правової доктрини вже багато років досліджується й обговорюється. Однак відсутність правового регулювання поширеної та, зазначимо, доволі ефективної процедури врегулювання спорів $€$ перепоною у процесі позасудового регулювання трудових спорів. При цьому неодноразово на розгляд Верховної Ради України подавалися проєкти законів про медіацію. Також слід зазначити, що 7 серпня 2019 року Міністром юстиції України було підписано від імені України Конвенцію ООН про Міжнародні угоди про врегулювання спорів за результатами медіації (Сінгапурська конвенція про медіацію). 3 метою ратифікації та імплементації вказаної Конвенції на сьогодні у Верховній Раді зареєстровано законопроєкт № 3504 від 19.05.2020, який визначає основні положення, зокрема щодо сфери застосування медіації, процедури іiї проведення та статусу медіаторів. Відповідно до зазначеного документа медіацію пропонується розглядати як добровільну, конфіденційну, структуровану процедуру, під час якої сторони за допомогою медіатора (медіаторів) намагаються врегулювати конфлікт (спір) шляхом переговорів. При цьому ст. 2 відповідного законопроєкту визначає, що медіація може застосовуватися в будьяких конфліктах (спорах), у тому числі тих, які виникають із трудових правовідносин [9].

Зазначимо, що відсутність належного правового регулювання медіації в Україні $є$ не єдиною проблемою на шляху до поширення цієї процедури для врегулювання спорів. Друга перешкода полягає у відсутності обізнаності громадян і сформованій ментальності звертатися виключно до судових органів для розв'язання правових конфоліктів. Окрім того, на сьогодні велике питання викликає наявність в Україні осіб, які належним чином кваліфіковані для виконання обов'язків медіатора. Отже, можемо підсумувати, що есрективне запровадження в Україні процедури медіації вимагає, по-перше, належного законодавчого забезпечення, тобто прийняття відповідного закону та підзаконних нормативноправових актів на його виконання, по-друге, створення відповідних центрів із підготовки медіаторів і акредитації (переакредитації) уже існуючих, по-третє, проведення відповідної інформаційної політики для інформування населення про альтернативні способи розв'язання їхніх спорів і переваги таких способів.

II. Примирення як альтернативний спосіб розв'язання трудових спорів. Як зазначає Єнікєєв М. І., сутністю примирення як способу правового регулювання спору є його відновлювана фрункція, спрямована на зведення суспільних відносин до стану, у якому такі відносини перебували до їх порушення [10, с. 234]. Аналізуючи міжнародне законодавство, зазначимо, що держави, зокрема держави-члени $€ C$, закріпили у положеннях трудових кодексів такий спосіб урегулювання трудового спору як примирення. Наприклад, у главі 12 Трудового кодексу Республіки Польща передбачене положення про можливість реалізації процедури примирення між сторонами трудового спору [11]. Така процедура здійснюється шляхом залучення примирних комісій. Роботу комісія починає за наявності відповідної заяви працівника. Законодавством Республіки Польща встановлено 14-денний термін для фактичного врегулювання спору, який відраховується з моменту подання заяви працівником. У виняткових випадках зазначений термін може бути продовжено ще на 15 днів. Примирна комісія надає учасникам справи пропозиції щодо можливих варіантів розв'язання спору. Примирна комісія припиняє свою роботу, якщо сторони конфлікту не дійшли примирення. У такому випадку примирна комісія може передати справу на розгляд суду. Не встановлено в законодавстві Республіки Польща чіткого механізму примусового виконання рішень, ухвалених за результатами проведення примирення. Установлено лише, що особа може звернутися до суду, якщо прийняте рішення не виконується іншою стороною.

Відповідна процедура примирення існує також у Франції. Трудове законодавство визначає, що будьякий спір може бути предметом примирення. Статті 2522-1 та 2522-13 Трудового кодексу Франції передбачають процедуру примирення. Слід зазначити, що порядок здійснення зазначеної процедури дуже схожий із тим, що встановлений у законодавстві Республіки Польща і був нами розглянутий вище. Так, у Франції існують спеціальні комісії, діяльність яких спрямована на досягнення примирення між сторонами трудового спору. Водночас, на відміну від законодавства Республіки Польща, французьке законодавство не встановлює конкретного терміну примирення, а лише визначає критерій розумності в аспекті тривалості процедури.

Аналізуючи українське законодавство, можемо зазначити, що, як і процедура медіації, примирення як спосіб урегулювання трудового спору не знайшло належного законодавчого закріплення. Поодинокі норми містяться в Законі України "Про порядок розв'язання колективних трудових спорів (конфрліктів)", які, зазначимо, не реалізуються на практиці. Детально проаналізувавши чинне трудове законодавство України, зазначимо, що певною мірою комісії із трудових спорів можна визначити як органи, що здійснюють альтернативне врегулювання трудового спору шляхом примирення. Зокрема, ст. 224 Кодексу законів про працю України визначає, що комісія із трудових спорів $є$ обов'язковим первинним органом із розгляду трудових спорів, що виникають на підприємствах, в установах, організаціях. У тому разі, якщо процедура, проведена комісією, не влаштує одну зі сторін спору, то згідно зі ст. 228 Кодексу законів про працю України відповідний суб'єкт може звернутися до суду з метою оскарження рішення комісії [12]. Незважаючи на те, що чинне законодавство передбачає функціонування відповідних комісій, можемо констатувати, що цей інститут на сьогодні здебільшого $€$ декларативним і не працює на практиці. На багатьох підприємствах комісії або не створюються взагалі, або створюються лише "на папері" й не здійснюють розгляд трудових спорів, якщо такі виникають. Законодавче регулювання процедури проведення розгляду спору також відсутнє. Зазначимо, що проєкт Трудового кодексу передбачає фрункціонування комісії з трудових спорів як органу, завданням якого $€$ сприяння розв'язанню індивідуальних трудових спорів шляхом усунення порушень прав працівників, пошуку взаємоприйнятних рішень і примирення сторін індивідуальних трудових спорів. Проєкт визначає порядок проведення прими- 
рення, установлює терміни його здійснення, визначає зміст рішення. Передбачається, що рішення комісії 3 трудових спорів приймається за згодою між представниками роботодавця та працівників, які беруть участь у іiї засіданні. Рішення вважається прийнятим, якщо його підтримано більшістю голосів представників кожної зі сторін. Рішення комісії з трудових спорів підлягає добровільному виконанню у визначені в ньому терміни [13]. Безумовно, позитивним кроком $є$ те, що проєкт передбачає функціонування комісії з трудових спорів як органу примирення, доволі детально визначає порядок здійснення зазначеної процедури. При цьому слід зазначити, що, на противагу європейському законодавству, проєкт не передбачає можливості неухвалення комісією рішення в тому разі, якщо запропоноване рішення не влаштовує сторонт. А оскільки проєктом передбачається виключно добровільне виконання, то можемо констатувати, що виконуватися будуть лише ті рішення, які задовольняють сторони. Недоліком даної процедури також може бути суб'єктивізм її членів, а отже, і розроблення такого рішення, яке буде здебільшого відстоювати інтереси роботодавця, а не працівника. Водночас примирення, безумовно, має свої переваги. До них можна віднести швидкість і економічність процедури, створення передумов для належного функціонування відповідної сорери трудових відносин, можливість зберегти нормальний стан реалізації трудових відносин і попередити виникнення аналогічного трудового спору в майбутньому.

III. Арбітраж (третейські процедури) як альтернативний спосіб урегулювання трудового спору. Арбітражний розгляд трудового спору полягає у розв'язанні відповідних суперечок у межах недержавних незалежних органів, які утворюються за домовленістю сторін конфллікту та спрямовують свою діяльність на розгляд і розв'язання спору, що виник між цими сторонами. На сьогодні в Україні діє Закон України "Про третейські суди", який у межах ст. 2 визначає, що третейський суд це недержавний незалежний орган, що утворюється за згодою або відповідним рішенням заінтересованих фрізичних та/або юридичних осіб у порядку, установленому законом, для розв'язання спорів, що виникають із цивільних і господарських правовідносин. Стаття 6 визначає, що до компетенції третейських судів в Україні не належать розгляд і розв'язання трудових спорів [14].

Слід зазначити, що інша ситуація склалася в межах європейського правового регулювання. Наприклад, у Трудовому кодексі Франції встановлено, що в трудовому договорі може бути передбачено можливість застосування арбітражної процедури для врегулювання трудового спору. Арбітр обирається за згодою сторін. Сторони мають забезпечити доступ арбітра до всіх документів, які необхідно дослідити для розв'язання спору. При цьому арбітр не може розглядати питання, які виходять за межі наявного конфлікту. Рішення, прийняті арбітражним судом, є обов'язковими для виконання. Перевагою такого способу розв'язання спору $€$ його ефективність, швидкість і результативність. Недоліком може бути висока вартість самої процедури. Однак, на наш погляд, арбітражний розгляд може бути гарною альтернативою судовому розгляду, який здебільшого вимагає значних затрат часу та зусиль обох сторін спору. 3 огляду на це вважаємо за доцільне передбачити в чинному законодавстві можливість розгляду трудових спорів третейськими судами.

ВИСНовКИ. Таким чином, нами були проаналізовані три основні позасудові способи врегулювання трудових спорів. Разом із тим зазначимо, що перелічені способи не є вичерпними, адже законодавство кожної конкретної держави, ураховуючи власну правову сис- тему та культуру, розробляє такі способи, які є ефективними для регулювання конкретної сфери. Що ж до України, то на сьогодні альтернативні способи розв'язання трудових спорів застосовуються в доволі вузькій площині, що обумовлено як браком правового регулювання, так і необізнаністю населення і небажанням застосовувати так звані "мирні" процедури врегулювання спору. 3 огляду на це, а також з метою розвантаження національної судової системи, ми переконані, що запровадження обов'язкового досудового врегулювання трудових спорів може стати цілком виправданим кроком.

Отже, оцінюючи досвід іноземних держав, зокрема європейських, як позитивний в аспекті функціонування альтернативних способів розв'язання трудових спорів, вважаємо за необхідне здійснити осучаснення відповідного пласту національного законодавства. Обрана та розглянута проблематика, у свою чергу, потребує подальшого ґрунтовного доктринального дослідження та вивчення.

\section{Список використаних джерел:}

1. Про порядок вирішення колективних трудових спорів (конфліктів): Закон України. URL: https://zakon.rada.gov.ua/laws/show/137/98-\% D0\%B2\%D1\%80 (дата звернення: 19.06.2020)

2. Юридична енциклопедія в 6 томах за ред. Ю. С. Шемшученко. Київ: Видавництво "Українська енциклопедія" імені М. П. Бажана, 2004. 765 c.

3. Толкунова В. Н. Трудовое право: курс лекций. Москва: ООО "ТК Велби", 2003. 320 с

4. Вавженчук С.Я. Система захисту і охорони конституційних трудових прав працівників: монографія. Харків, 2013. 510 с.

5. Альтернативні способи вирішення трудових спорів. В. Я. Бурак, Л. В. Кулачок-Тітова, П. Д. Пилипенко, Н.І.Чудик-Білоусова ; під ред. У. Гелльманна, П. Д. Пилипенка. Хмельницький : Хмельницький університет управління та права, 2015. 172 с

6. Про деякі аспекти медіації в цивільних і господарських спорах від 21.05.2008: директива Європейського парламенту. URL: https://zakon.rada.gov.ua/laws/show/994 a95 (дата звернення: 19.06.2020)

7. Code du travail. URL: http://codes.droit.org/CodV3/travail.pdf (dama звернення: 19.06.2020)

8. Про медіацію (посередництво) від 17. 12. 2004: Закон Республіки Болгарія. URL: https://issuu.com/uccg/docs/25_bulgarian_mediation state act ukr (дата звернення: 19.06.2020)

9. Про медіацію: проект Закону України № 3504 від 19.05.2020. URL: http://w1.c1.rada.gov.ua/pls/zweb2/webproc4_1?pf3511=68877 (даma звернення: 19.06.2020)

10. Еникеев, М. И. Основы общей и юридической психологии : учеб. для вузов. Москва.: Юристь, 1996. 631 с.

11. Ustawa z dnia 26 czerwca 1974r. Kodeks pracy. URL: http://prawo.sejm.gov.pl/isap.nsf/DocDetails.xsp?id=WDU19740240141 (дата звернення: 19.06.2020)

12. Кодекс законів про працю України в редакції від 20.03.2020. URL: https://zakon.rada.gov.ua/laws/show/322-08\#top (дата звернення: 19.06.2020)

13. Проект Трудового кодексу № 2410 від 08.11.2019. URL: https://w1.c1.rada.gov.ua/pls/zweb2/webproc4 1?pf3511=67331 (Дama звернення: 19.06.2020)

14. Про третейські суди: Закон України від 11.05.2004. URL: https://zakon.rada.gov.ua/laws/show/170115?find=1\&text=\%D1\%82\%D1\%80\% D1\%83\%D0\%B4\%D0\%BE\%D0\%B2\#Text (дата звернення: 19.06.2020)

15. Terekhov V. Online Mediation: a Game Changer or Much Ado About Nothing?. 2019. \# 3 (2) Access to Justice in Eastern Europe 33-50. URL: http://ajee-journal.com/upload/attaches/att_1569575810.pdf (dama звернення: 19.06.2020)

16. Рєзнікова В. Медіація (посередництво) як спосіб вирішення господарських спорів. Вісник КНУ. № 90. 2012. С. 10-15. URL: http://visnyk.law.knu.ua/images/pdf/90_2012.pdf (дата звернення: 19.06.2020)

17. Ізарова І.О. Теоретичні засади цивільного процесу ЄС: монографія. Київ : ВД Дакор, 2015. 336 с.

References:

1. Pro poryadok vyrishennya kolektyvnykh trudovykh sporiv (konfliktiv): Zakon Ukrayiny. URL: https://zakon.rada.gov.ua/laws/show/137/98$\% \mathrm{D} 0 \% \mathrm{~B} 2 \% \mathrm{D} 1 \% 80$ [in Ukrainian]

2. Yurydychna encyklopediya $v \quad 6$ tomakh za red. Yu. S. Shemshuchenko. Kyyiv: Vydavnycztvo "Ukrayinska encyklopediya" imeni M. P. Bazhana, 2004. 765 s. [in Ukrainian]

3. Tolkunova V. N. Trudovoe pravo: kurs lekcyj. Moskva: OOO "TK Velby", 2003. 320 s. [in Russian]

4. Vavzhenchuk S.Ya. Systema zakhystu i okhorony konstytucijnykh trudovykh prav pracivnykiv: monografiya. Kharkiv, 2013. 510 s. [in Ukrainian] 
5. Alternatyvni sposoby vyrishennya trudovykh sporiv. V. Ya. Burak, L. V. Kulachok-Titova, P. D. Pylypenko, N. I. Chudyk-Bilousova; pid red U. Gellmanna, P. D. Pylypenka. Khmelnyczkyj : Khmelnyczkyj universytet upravlinnya ta prava, 2015. $172 \mathrm{~s}$. [in Ukrainian]

6. Pro deyaki aspekty mediaciyi $v$ cyvilnykh i gospodarskykh sporakh vid 21.05.2008: dyrektyva Yevropejskoho parlamentu. URL: https://zakon.rada.gov.ua/laws/show/994_a95 [in Ukrainian]

7. Code du travail. URL: http://codes.droit.org/CodV3/travail.pdf [in French]

8. Pro mediaciyu (poserednycztvo) vid 17. 12. 2004: Zakon Respubliky Bolgariya. URL: https://issuu.com/uccg/docs/25 bulgarian_mediation_state act_ukr [in Ukrainian]

9. Pro mediaciyu: proekt Zakonu Ukrayiny №3504 vid 19.05.2020. URL: http://w1.c1.rada.gov.ua/pls/zweb2/webproc4_1?pf3511=68877 [in Ukrainian]

10. Enykeev, M. Y. Osnovy obshhej yurydycheskoj psykhologyy: ucheb. dlya vuzov. Moskva.: Yuryst, 1996. $631 \mathrm{~s}$. [in Russian]

11. Ustawa $z$ dnia 26 czerwca 1974r. Kodeks pracy. URL: http://prawo.sejm.gov.pl/isap.nsf/DocDetails.xsp?id=WDU19740240141 [in Polish]

O. Terekh, PhD (Law), Teaching Assistant

Taras Shevchenko National University of Kyiv, Kyiv, Ukraine
12. Kodeks zakoniv pro pracyu Ukrayiny v redakciyi vid 20.03.2020. URL: https://zakon rada gov.ua/laws/show/322-08\#top [in Ukrainian]

13. Proekt Trudovogo kodeksu № 2410 vid 08.11.2019. URL: https://w1.c1.rada.gov.ua/pls/zweb2/webproc4_1?pf3511=67331 [in Ukrainian] 14. Pro tretejski sudy: Zakon Ukrayiny vid 11.05.2004. URL: https://zakon.rada.gov.ua/laws/show/170115?find=1\&text=\%D1\%82\%D1\%8 \% $1 \% 83 \% \mathrm{D} 0 \% \mathrm{~B} 4 \% \mathrm{D0} \% \mathrm{BE} \% \mathrm{D} 0 \% \mathrm{~B} 2$ \#Text [in Ukrainian]

15. Terekhov V. Online Mediation: a Game Changer or Much Ado About Nothing?. 2019. \# 3 (2) Access to Justice in Eastern Europe 33-50. URL: http://ajee-journal.com/upload/attaches/att 1569575810.pdf [in English]

16. Ryeznikova V. Mediaciya (poserednycztvo) yak sposib vyrishennya hospodarskyx sporiv. Visnyk KNU. \# 90. 2012. S. 10-15. URL: http://visnyk.law.knu.ua/images/pdf/90_2012.pdf [in Ukrainian]

17. Izarova I.O. Teoretychni zasady cyvilnoho procesu YeS : monografiya. Kyyiv : VD Dakor, 2015. 336 s. [in Ukrainian]

Received: $20 / 05 / 2020$

1st Revision: $15 / 06 / 2020$ Accepted: 25/06/2020

\section{ALTERNATIVE WAYS TO RESOLVE LABOUR DISPUTES: PRACTICE OF UKRAINE AND THE EU}

This article explores alternative ways of resolving labour disputes through the analysis of relevant regulations of Ukraine and the Member States of the European Union, in particular, France, Bulgaria and Poland, and compares the relevant regulations in this area by contrasting the provisions of domestic and foreign legislation.

The purpose of the article is to explore the ways to alternatively resolve labour disputes by analyzing the relevant legal doctrine and provisions of domestic and European law, to identify the advantages and disadvantages of such methods as mediation, conciliation, arbitration, to suggest ways to improve existing legislation.

It is noted that the lack of proper legal regulation of alternative dispute resolution today is not the only. Thus, it emphasizes the need to train personnel who could perform the functions of mediators in labour disputes, as well as the need to conduct a comprehensive information policy to inform the public about the benefits of alternative dispute resolution as opposed to litigation, to which the author, in particular, relates the speed, efficiency and focus on maintaining labour relations. In addition, consideration is given to the feasibility of introducing mandatory pre-trial procedures for the settlement of labour disputes.

The results of the study can be used for further research in the study of alternative ways of resolving labour disputes, and the formulated proposals can be used to improve existing legislation in the field of labour disputes.

Keywords: a labor conflict, mediation, conciliation, arbitration courts, arbitration, a labor dispute commission.

Bulletin of Taras Shevchenko National University of Kyiv. Legal Studies, 2020; 2 (113): 66-71

УДК: 349.6

DOI: https:doi.org/10.17721/1728-2195/2020/2.113-13
ISSN 1728-2195

C Taras Shevchenko National University of Kyiv, Publishing center "Kyiv University", 2020

ORCID ID: 0000-0001-7152-0108

Київський національний університет імені Тараса Шевченка, Київ, Україна

\section{ОСОБЛИВОСТІ ПРАВОВОГО СТАНОВИЩА ВИРОБНИКІВ СИРОВИНИ ДЛЯ ДИТЯЧОГО ХАРЧУВАННЯ}

Досліджено правове становище виробників сировини для дитячого харчування в Україні. Установлено, що в законодавстві України відсутній єдиний підхід до визначення поняття "сільськогосподарський товаровиробник", що може призводити до негативних наслідків у правозастосуванні. Висвітлено правові питання загальної, спеціальної та особливої правосуб'єктності виробників сировини рослинного і тваринного походження для дитячого харчування. Установлено, що виробники сільськогосподарської сировини для дитячого харчування наділені спеціальною правосуб'єктністю, що проявляється крізь призму виконання ними обов'язку виробництва якісної та безпечної сільськогосподарської сировини. Проаналізовано сучасне правове становище спеціальних сировинних зон із виробництва сировини, що використовується для виготовлення продуктів дитячого та дієтичного харчування. Наголошено на необхідності встановлення законодавчої заборони на будь-яке застосування пестицидів на території спеціальних сировинних зон. Зазначено, що ті суб'єкти агробізнесу, які провадять свою діяльність у спеціальних сировинних зонах, спроможні забезпечити виробників дитячого харчування екологічно чистою та безпечною сировиною тваринного і рослинного походження. Водночас такі суб'єкти майже не мають жодних переваг перед сільськогосподарськими товаровиробниками без статусу спеціальної сировинної зони. Акцентовано увагу на негативній тенденції скорочення кількості спеціальних сировинних зон із виробництва сировини, яка використовується для виготовлення продуктів дитячого харчування. Констатовано, що існує нагальна потреба у створенні дієвого механізму державної підтримки суб'єктів агробізнесу, які отримали статус спеціальної сировинної зони. Зроблено висновок, що сільськогосподарські товаровиробники, які виробляють сировину у спеціальних сировинних зонах, наділені особливою правосуб'єктністю.

Ключові слова: генетично модифіковані організми, дитяче харчування, сільськогосподарська сировина, сільськогосподарський виробничий кооператив, спеціальна сировинна зона, пестициди й агрохімікати, фермерське господарство, якість і безпечність продуктів харчування.

ВСТУП. Виробництво сільськогосподарської сировини для дитячого харчування є стратегічно важливим напрямом виробничо-господарської економіки України в аграрному секторі. Виробництво якісної та безпечної сільськогосподарської сировини рослинного і тваринно- го походження, яка використовується для виготовлення дитячого харчування, дозволяє гарантувати конституційне право дитини на достатнє харчування, а також підтримувати належний стан продовольчої безпеки держави. На сьогоднішній день існує велике різноманіт- 